\title{
Pregnancy outcomes of women with polycystic ovary syndrome for the first in vitro fertilization treatment: A retrospective cohort study with 7678 patients
}

\author{
Su Liu ${ }^{1}$, Meilan $\mathrm{Mo}^{1}$, Shan Xiao ${ }^{1}$, Longfei $\mathrm{Li}^{1}$, Xiuyu Hu${ }^{1}$, Ling Hong ${ }^{1}$, Linlin Wang ${ }^{1}$, \\ Ruochun Lian ${ }^{1}$, Chunyu Huang ${ }^{1}$, Yong Zeng ${ }^{1,2}$, and Lianghui Diao ${ }^{1}$ \\ ${ }^{1}$ Shenzhen Zhongshan Urology Hospital \\ ${ }^{2}$ Shenzhen University
}

June 8, 2020

\begin{abstract}
Objective: To evaluate whether polycystic ovary syndrome (PCOS) affects pregnancy outcomes and complications in infertile women undergoing their first in vitro fertilization (IVF) treatment. Design: A retrospective cohort study. Setting: Private fertility center. Population: 7678 infertile women, including 666 women with PCOS and 7012 controls undergoing their first IVF treatment from 2010 to 2017. Methods: Maternal characteristics, pregnancy outcomes and complications were analyzed by independent t-test, Mann-Whitney U-test, or Chi-square test. A logistic regression analysis was performed to determine the impact of PCOS on pregnancy outcomes and complications. Main Outcome Measures: Risk of adverse pregnancy outcomes (miscarriage, preterm delivery, pregnancy-induced hypertension) and pregnancy outcomes (live birth rate, clinical pregnancy rate, implantation rate), adjusted for maternal characteristics. Results: After adjusting for differences in maternal age, BMI, infertility duration, total dose of gonadotropin, serum E2 and endometrial thickness on the day of hCG trigger, number of fertilized occytes, number of embryos transferred, embryo type (cleavage-stage embryo or blastocyst) and quality, women with PCOS had an increased risk of developing unfavorable pregnancy complications, including miscarriage (adjusted odds ratio [aOR] 1.629, 95\% confidence interval [CI] 1.240-2.141), very preterm delivery (< 32 weeks) (aOR 2.135, 95\% CI 1.170-3.895). For pregnancy outcomes, PCOS was associated with higher clinical pregnancy rate (aOR 1.248, 95\% CI 1.038-1.501) and implantation rate (aOR 1.238, 95\% CI 1.030-1.489) after adjusting for the above-mentioned confounders. Conclusions: Women with PCOS are at increased risk of adverse pregnancy outcomes. These women may need more frequent medical consultants and management during pregnancy and parturition.
\end{abstract}

\section{INTRODUCTION}

Polycystic ovary syndrome (PCOS) is one of the most common endocrine disorders that affects $5 \%-15 \%$ in women of reproductive age, depending on the population studied and the diagnostic criteria used (1). The most common features of PCOS are oligo- or anovulation, hyperandrogenism, and polycystic ovaries (2). Other endocrinal disorders such as insulin resistance and obesity play essential roles in the pathogenesis of PCOS $(3,4)$. These endocrinal diseases are also known risk factors to induce metabolic syndrome, pregnancy loss and late pregnancy complications, which indicates that PCOS is a chronic disease that impacts women across the lifespan (5).

Previous studies have reported an increased risk of pregnancy complications, such as gestational diabetes mellitus (GDM), pregnancy-induced hypertension (PIH), and preterm delivery in the PCOS population (68). However, the pathophysiological explanation is debated, as in these studies, several characteristics of the PCOS population, including maternal age, body mass index (BMI) and the use of assisted reproductive technologies may independently contribute to adverse pregnancy outcomes and thus confound the study 
conclusions. To our knowledge, there have been very few studies on pregnancy outcomes in women with PCOS, accounting for all the relevant confounders. Consequently the extent to which the risk of pregnancy complications in women with PCOS is attributed to the underlying disorder is uncertain. Therefore, to drive a more precise estimation of the risks of pregnancy complications in women with PCOS, we conducted this retrospective study to investigate the prevalence of adverse pregnancy outcomes in women with PCOS by comparison with control group after adjusting for other relevant confounders.

\section{MATERIALS AND METHODS}

\section{Participants}

We identified 9074 patients from Shenzhen Zhongshan Urology Hospital (SZUH) who had their first IVF treatment between January 2010 and December 2017. From the original cohort, we excluded patients who had virus infection (including HBV, HCV, HIV, and syphilis) $(\mathrm{n}=160)$. Patients aged $>38$ years $(\mathrm{n}=561)$ and those treated with gonadotropin-releasing hormone $(\mathrm{GnRH})$-antagonist controlled ovarian hyperstimulation $(\mathrm{COH})$ protocols $(\mathrm{n}=196)$ were also excluded. We also excluded the cycles missing embryo information and clinical pregnancy data, patients suffering from a chromosomal abnormality, intrauterine death, a medical abortion, stillbirth, or ectopic pregnancy $(n=479)$. PCOS was diagnosed if patients meet two or three of the following criteria: (1) oligo- or amenorrhoea; (2) biochemical or clinical hyperandrogenism; (3) multifollicular appearance of ovaries on transvaginal ultrasound scan, according to the Rotterdam criteria. Finally, the study population consisted of 666 women diagnosed with PCOS and 7012 controls (Supplemental Figure 1 ). The Institutional Review Board of Reproductive Research Ethics Committees of Shenzhen Zhongshan Urology Hospital approved this study (Approval number: SZZSECHU-20180030).

\section{In vitro fertilization and embryo transfer protocols}

All patients' information, including their baseline characteristics, cycle characteristics, and pregnancy outcomes were extracted from the electronic medical record. All included patients underwent IVF cycles receiving a routine luteal phase down-regulation protocol with $\mathrm{GnRH}$ agonist protocol. The gonadotropin starting dose and the GnRH analogue were selected based on the physician's discretion. Monitoring of ovarian response was assessed by serum $\mathrm{E}_{2}$ levels and transvaginal ultrasound scan. Final oocyte maturation was induced by injection of human chorionic gonadotropin (hCG) when at least two follicles reached 17-18 $\mathrm{mm}$. Transvaginal ultrasound guided oocyte retrieval was carried out 36 hours following hCG injection. Traditional IVF or intracytoplasmic sperm injection (ICSI) was performed as indicated. Embryo quality was evaluated by two experienced embryologists based on the number of blastomeres and the percentage of fragmentation. Ultrasound-guided fresh embryo transfer was performed on day 3 or day 5 after fertilization.

\section{Measurement of outcomes}

Pregnancy outcomes including implantation rate, clinical pregnancy rate and live birth rate were collected and measured. Adverse pregnancy outcomes such as miscarriage, multiple pregnancies, preterm delivery, GDM, PIH were reported and the incidence of each complication was measured. The implantation rate was calculated by the number of intrauterine gestational sacs per transferred embryo. Clinical pregnancy was defined by the sonographic presence of a gestational sac at 7-8 weeks of gestation. Live birth rate was calculated as cycles with delivered live babies divided by the number of total embryo transferred cycles. Miscarriage included early miscarriage (pregnancy loss before 12 weeks of gestation) and late miscarriage (pregnancy loss within 12-28 weeks of gestation). Preterm delivery was defined as delivery at $<37$ completed gestational weeks and stratified into very preterm delivery $(<32$ weeks) and moderately preterm birth $(32-36$ weeks). GDM was performed at 24 weeks of gestation and defined as plasma glucose levels $>10 \mathrm{mmol} / \mathrm{L}$ after a 2-hour oral glucose tolerance test with $75 \mathrm{~g}$ of glucose. PIH was described as hypertension with a systolic blood pressure over $140 \mathrm{~mm} \mathrm{Hg}$ or diastolic blood pressure over $90 \mathrm{~mm} \mathrm{Hg}$, with or without proteinuria, developing after 20 weeks of gestation.

\section{Statistical analysis}

Descriptive statistical analysis was performed on main maternal and cycle characteristics. Continuous data 
with normal distribution were presented as the mean \pm standard deviation (SD) and analyzed by independent $t$-test. The continuous variables that did not show a normal distribution were presented as median and interquartile range, and were analyzed by Mann-Whitney $U$-test. Categorical data were presented by the number of cases and corresponding percentage, and were analyzed by Pearson's $\chi^{2}$ test or Fisher's exact test.

To assess the relationships between PCOS and different pregnancy outcomes, logistic regression analysis, adjusted for potential confounding covariates, were performed. The selection of variables was based on identifying all measured clinical variables of known or suspected prognostic importance for the outcome of interest. For adverse pregnancy outcomes, two multivariable regression models were analyzed; model 1 only includes maternal age and BMI, whereas model 2 includes maternal age, BMI and other variables that exhibit a $P$-value of $<0.05$ in the univariate analysis. The number of oocytes retrieved was not putted in the regression model as it is highly correlated with both serum $\mathrm{E}_{2}$ level and number of fertilized occytes (Supplemental Table 1 ). All $P$ values are two sided and statistical significance was established as $P$ $<0.05$. All analyses were conducted using SPSS (version 23.0; SPSS Inc.).

\section{RESULTS}

\section{Population characteristics}

A total of 7678 couples undergoing their first IVF treatments between 2010 and 2017 were included in the cohort, with 666 women diagnosed with PCOS and 7012 controls. The prevalence of PCOS was $8.7 \%$ in this study population.

The women with PCOS were slightly younger (30.0 vs. 31.0 years; $P<0.001)$, had a higher BMI (22.3 vs. $\left.20.7 \mathrm{~kg} / \mathrm{m}^{2} ; P<0.001\right)$, and longer infertility duration (3.8 vs. 3.7 years; $\left.P<0.001\right)$ compared with the control group (Table 1 ). The PCOS population was more frequently diagnosed with primary infertility (66.8\% vs. $51.2 \% ; P<0.001)$. More ovulatory disorders ( $73.4 \%$ vs. $0.5 \% ; P<0.001)$, lower baseline serum FSH level $(5.1$ vs. $5.6 \mathrm{IU} / \mathrm{L} ; P<0.001)$ were found in the PCOS group compared with the control group.

Compared with the control group, longer duration of gonadotropin stimulation (10.0 vs. 9.0 days; $P<0.001$ ), less gonadotropin was used $(1650.0$ vs. $2400.0 \mathrm{IU} ; P<0.001)$ and higher serum $\mathrm{E}_{2}$ levels on the day of hCG trigger (2602.0 vs. $2495.0 \mathrm{pg} / \mathrm{mL} ; P=0.040)$ were noticed in the PCOS group. There was no significant difference in endometrial thickness before embryo transfer between these two groups $(P=0.737)$.

In the present study, PCOS women had a trend towards more oocytes retrieved (15.0 vs. $13.0 ; P<0.001)$ and higher number of fertilization $(12.0$ vs. $10.0 ; P<0.001)$, as well as fewer transferred embryos $(2.2$ vs. 2.4; $P<0.001)$. A higher frequency of IVF ( $80.5 \%$ vs. $75.3 \% ; P=0.003)$ and more cycles with high-quality embryos were found in PCOS group compared with the control group (97.6\% vs. 95.0\%; $P=0.002)$. Embryo type (cleavage-stage embryo or blastocyst) did not differ significantly between the two groups $(P=0.430)$.

\section{Pregnancy outcomes}

The implantation rate, clinical pregnancy rate and live birth rate were significantly higher in the PCOS group compared with the control group $(49.3 \%$ vs. $38.1 \%, 70.9 \%$ vs. $59.8 \%, 58.3 \%$ vs. $52.1 \%$, respectively; $P$ $<0.001, P<0.001, P=0.002$, respectively, see Table 2 ). Nevertheless, the delivery type (cesarean or eutocia) exhibited no difference between these two groups $(P=0.967)$. As for the adverse pregnancy outcomes, miscarriage and multiple pregnancies were more common among women with PCOS diagnosis than among those without ( $16.5 \%$ vs. $11.2 \%, 42.0 \%$ vs. $35.8 \%$, respectively; $P=0.001, P=0.016$, respectively). In addition, women with PCOS were more prone to deliver preterm ( $<37$ weeks) than the control group $(26.5 \%$ vs. $21.9 \% ; P=0.039)$. The very preterm delivery rate $(<32$ weeks $)$ was also significantly higher in the PCOS group $(3.9 \%$ vs. $1.6 \% ; P=0.002)$. PIH were more often reported in the PCOS group $(3.9 \%$ vs. $2.2 \% ; P$ $=0.031)$. However, the morbidity of GDM was similar in both groups $(P=0.665)$.

Logistic regression analysis was performed to analyze the association between PCOS and the pregnancy outcomes (Table 3, Table 4 and Supplemental Table 2 ). As indicated in Table 3, more live births were 
positively correlated with a PCOS diagnosis, younger age, shorter duration of infertility, less gonadotropin used, higher $\mathrm{E}_{2}$ levels and thicker endometrial thickness on the day of hCG trigger, more oocytes retrieved and fertilized, fewer embryos transferred, but more blastocysts and higher-quality embryos transferred. After adjusted for maternal age and BMI, women with PCOS still had a higher live birth rate (aOR 1.213, 95\% CI 1.027-1.433, $P=0.023)$. However, after correcting for the effects of all the above-mentioned confounders, a PCOS diagnosis was no longer associated with a higher live birth rate (aOR 1.012, 95\% CI 0.852-1.204,P $=0.888$ ). As for clinical pregnancy outcome, when these factors were adjusted for, having a PCOS diagnosis remained associated with a higher clinical pregnancy rate (aOR 1.248, 95\% CI 1.038-1.501, $P=0.019$ ).

Multiple logistic regression showed that the PCOS diagnosis, maternal age, BMI, duration of infertility, serum $\mathrm{E}_{2}$ level and endometrial thickness on the day of hCG trigger, number of embryos transferred, embryo type and quality were all significantly correlated with miscarriage on univariate analysis (Table 4 ). After controlling for maternal age and BMI, miscarriage was still positively correlated with a PCOS diagnosis (aOR 1.585, 95\% CI 1.210-2.078, $P=0.001$ ). Moreover, a secondary analysis was performed including all the above-mentioned factors in the model, which did not substantially alter the estimates, PCOS remained positively associated with an increased risk of miscarriage (aOR 1.629, 95\% CI 1.240-2.141, $P<0.001$ ).

In another multiple regression analysis (correcting for the effects of a PCOS diagnosis, age, BMI, number of embryos transferred and embryo type), younger maternal age, more embryo transferred and more blastocysts were associated with an increased risk of preterm delivery before 37 weeks of gestation. However, a PCOS diagnosis was not associated with preterm delivery before 37 weeks of gestation in this analysis (aOR 1.206, $95 \%$ CI $0.937-1.552, P=0.145)$. For the very preterm delivery ( $<32$ weeks), after adjust for maternal age and BMI (since no other confounders were found according to the univariate logistic regression model), a PCOS diagnosis (aOR 2.135, 95\% CI 1.170-3.895, $P=0.013$ ) and higher BMI remained associated with an increased risk of preterm delivery before 32 weeks of gestation.

PCOS was no longer associated with increased risk of PIH after adjusting for age, BMI, duration of infertility and serum $\mathrm{E}_{2}$ level (aOR 1.764, 95\% CI 0.981-3.171, $P=0.058$ ). Moreover, we also performed a stratified analysis for these adverse pregnancy outcomes among women overweight or with obesity defined by a BMI over $25 \mathrm{~kg} / \mathrm{m}^{2}$ and those with a BMI less than $25 \mathrm{~kg} / \mathrm{m}^{2}$ (Supplemental Table 3 ).

\section{DISCUSSION}

\section{Main findings}

In the present study, we found that women with PCOS had higher live birth rate, clinical pregnancy rate and implantation rate, as well as an increased risk of pregnancy complications (miscarriage, preterm delivery and $\mathrm{PIH}$ ) in their first IVF treatment when compared with non-PCOS controls. Among all these outcomes, higher clinical pregnancy rate, implantation rate, miscarriage rate, and very preterm delivery rate $(<32$ weeks) were still maintained in the PCOS population after adjusting for the following risk factors: maternal age, BMI, infertility duration, total dose of gonadotropin, serum $\mathrm{E}_{2}$ level and endometrial thickness on the day of hCG trigger, number of fertilized occytes, number of embryos transferred, embryo type and quality.

\section{Strengths and limitations}

An important strength of this study is the large size of the cohort, which enabled us to include more relevant confounders to provide a more precise estimation of the risks of pregnancy complications in women with PCOS than in former studies. Additionally, we were able to distinguish between preterm and very preterm delivery, which is important as the relationship between PCOS and preterm delivery might differ according to gestational age. Moreover, subgroup analysis was performed to stratify risk for the pregnancy complications by lean vs. overweight/obese PCOS, which makes it possible to analyze the relationship between PCOS and adverse pregnancy outcomes under different subgroups.

Our study has a number of limitations. First, our study relied on self-reported data of pregnancy complications, which may lead to an underestimation of the prevalence of PIH and GDM. Second, the retrospective nature made it difficult to study several pregnancy and neonatal outcomes, such as antepartum hemorrhage, 
pre-eclampsia, birthweight, small or large for gestational age neonates. Furthermore, we were unable to stratify preterm delivery for cause (e.g. premature ruptures of membranes, cervical insufficiency) or spontaneous versus induced preterm delivery, or analyze between PIH and pre-eclampsia. Third, the results of this study cannot be generalized to all IVF cases since we only analyzed fresh embryo transfer cycles. Finally, it was not possible to stratify the prevalence of pregnancy complications follow the phenotypic variants of PCOS, as our study lacked the stratification of different PCOS phenotype.

\section{Interpretation}

We found a significant increase in the number of oocytes retrieved and fertilized in women with PCOS. We postulated that by retrieving more oocytes and achieving higher fertilization number, there could be more embryo selection, and therefore higher subsequent pregnancy rate. Moreover, a significantly increased live birth rate was observed in women with PCOS even after correcting for maternal age and BMI, however, this effect faded when adjusted for all the above-mentioned risk factors.

It is still debated whether women with PCOS have an increased risk of miscarriage compared with controls. Although available data show conflicting results, miscarriage rate was suggested to be comparable based on the PCOS consensus of 2012 (1). One meta-analysis showed no difference in miscarriage rate between women with PCOS and those without undergoing IVF (9). Our data showed a significantly increased risk of miscarriage among PCOS subjects compared with controls, which is consistent to a large Australian study also demonstrating that the miscarriage rate was more frequent in women with PCOS than in controls $(20 \%$ vs. $15 \% ; P=0.003)(10)$. Furthermore, in our study, the difference was still statistically significant after adjusting for important confounders. On subgroup analysis, the association between PCOS and miscarriage was only seen among the lean population after adjusting for age and BMI (aOR 1.599, 95\% CI 1.173-2.181,P $=0.003$ ). Unfortunately, we could not explain why this phenomenon occurred. However, our results indicate that there may be other intrinsic "PCOS factors" which may contribute to miscarriage except BMI.

Two meta-analyses demonstrated that women with PCOS have a 2-fold increased risk of preterm delivery $(6,7)$, whereas another meta-analysis demonstrated no effect (8). In a large Swedish study, infants born to mothers with PCOS were more frequently delivered prematurely (OR 2.21, 95\% CI 1.69-2.90) (11). Another cohort study confirmed an increased risk of preterm delivery (OR 2.02, 95\% CI 1.13-3.61) (12). Here, we observed an increased rate of preterm delivery before 32 weeks among PCOS subjects, but no difference in the rate of preterm delivery before 37 weeks after adjusting for the confounders based on the univariate logistic model. On subgroup analysis, there was a strong correlation between PCOS and preterm delivery before 37 weeks (aOR 1.369, 95\% CI 1.043-1.797, $P=0.024$ ) and very preterm delivery before 32 weeks (aOR 2.149, 95\% CI 1.095-4.217, $P=0.026$ ) among lean population. This finding was consistent with the previous study, which also showed that a significantly increased risk in preterm delivery was only found among the lean PCOS subjects (13). Hyperandrogenism, disturbed glucose metabolism and higher levels of inflammatory markers have been regarded as potential causes of preterm delivery in women with PCOS (12, 14). Since being born preterm has serious short- and long-term consequences, increased attention and closer follow-up of PCOS women during pregnancy might improve the outcome.

The higher rate of PIH (3.9\%) in women with PCOS in our study is similar with those in the literature $(3 \%-32 \%)(7)$. However, this figure is possibly an underestimate as patients may have underreported symptoms and/or may have been admitted to other hospitals and not informed the IVF unit. The mechanisms responsible for hypertension in women with PCOS may be explained as follows: first, insulin resistance could cause secondary hyperinsulinemia, which may produce enhanced sodium retention and play a role in the development of hypertension $(15,16)$; second, insulin could stimulate the release of insulin-like growth factor (IGF-1), which may determine the vascular smooth muscle hypertrophy and thus contribute to the hypertension (17); third, hyperandrogenemia also seems to be related to blood pressure (11). There have been three meta-analyses reported a three to four times increased risk of PIH in women with PCOS (6-8). Similarly, we observed increased rate of PIH in the PCOS population. However, after adjusting for the confounders, the prevalence of PIH among women with PCOS was somewhat higher but only borderline significant (aOR 1.764, 95\% CI 0.981-3.171,P =0.058), suggesting that there may be other risk factors con- 
tributing to PIH. On subgroup analysis, no significant different on the morbidity of PIH was seen among both lean and overweight/obese PCOS women.

GDM is the most commonly described pregnancy complication in women with PCOS. The early diagnosis and treatment could significantly reduce the incidence of related maternal and neonatal complications (18). Three meta-analyses reported a three times higher risk of GDM in women with PCOS (6-8). Among all the studies included, one Swedish population-based cohort study compared 3787 women with PCOS and 1191336 women without PCOS and showed than GDM was more than 2-fold higher in women with PCOS after adjusting data for confounders (OR 2.32, 95\% CI 1.88-2.88) (11). However, the women they included had more severe disease as exposed, and the findings may consequently not be generalizable to all women with PCOS. In this study, we observed the prevalence of GDM was 9.7\% among PCOS subjects, which is consistent with the reported rates (3\%-40\%) (19). However, we failed to find a statistically significant difference in the risk of GDM between women with PCOS and controls. This result may be partially explained by the relatively young population in our study, as many studies have indicated that advanced maternal age is an important risk factor for GDM $(20,21)$.

Multiple pregnancies are considered to be one of the most important adverse outcomes in patients following assisted reproductive technologies. Negative pregnancy complications associated with multiple gestations have been well documented, including increased risk of PIH, pre-eclampsia, preterm delivery, neonatal mortality and cesarean delivery $(22,23)$. The higher incidence of multiple pregnancies among PCOS patients in our study may therefore underlie the poorer observed outcomes. Moreover, although several studies have suggested that women with PCOS showed a higher rate of cesarean section, this was not observed in our study $(6-8,24)$.

Increasing evidences have showed a higher rate of pregnancy complications in women with PCOS. The increased incidence can partially be explained by higher BMI in women with PCOS. However, after adjusted for BMI, there seems to be an intrinsic "PCOS factors" which may contribute to pregnancy complications. Hyperandrogenism and insulin resistance characteristic of PCOS may play a crucial role during trophoblast invasion and placentation, and thus increase the long-term risk for mothers and children (12).

\section{Conclusion}

PCOS was associated with an increased risk of several pregnancy complications, such as miscarriage and preterm delivery, even after adjustments for all of those potential confounders. Although further multicenter prospective studies are required to validate our findings, our results indicate that women with PCOS undergoing IVF may need increased surveillance during pregnancy and parturition. Furthermore, pregnancy complications may influence long-term maternal health, such as cardiovascular disease and diabetes $(25,26)$. Thus, a better understanding of pregnancy complication rates among PCOS women will reduce the risk of both obstetric and neonatal complications and improve overall management of those patients.

\section{Disclosure of interests}

None declared.

\section{Contribution to authorship}

S.L., L.D. and Y.Z. are responsible for the concept and the study design. L.L. and L.W. performed the data collection, and S.L. did the statistical analysis. S.L. drafted the manuscript. M.M., S.X., X.H., L.H., R.L., and C.H. and contributed to the critical discussion, interpretation and editing of the manuscript.

\section{Details of ethics approval}

This study was approved by the Institutional Review Board of Reproductive Research Ethics Committees of Shenzhen Zhongshan Urology Hospital (Approval number: SZZSECHU-20180030).

\section{Funding}


Supported by Natural Science Foundation of Guangdong Province (2019A15150109), Sanming Project of Medicine in Shenzhen (SZSM201502035), National Natural Science Foundation of China (No. 81701529), Special Funds for Science, Technology Development of Guangdong Province (2017A020214006) and National Key Research \& Developmental Program of China (2018YFC1003900)

Acknowledgments: The authors are very grateful to the staff at the Fertility Center, Shenzhen Zhongshan Urology Hospital for their kind supports for collecting clinical data for this study.

\section{REFERENCES}

1. Fauser BC, Tarlatzis BC, Rebar RW, Legro RS, Balen AH, Lobo R, et al. Consensus on women's health aspects of polycystic ovary syndrome (PCOS): the Amsterdam ESHRE/ASRM-Sponsored 3rd PCOS Consensus Workshop Group. Fertil Steril. 2012;97(1):28-38 e25.

2. Rotterdam EA-SPCWG. Revised 2003 consensus on diagnostic criteria and long-term health risks related to polycystic ovary syndrome. Fertil Steril. 2004;81(1):19-25.

3. Lanzone A, Fulghesu AM, Cucinelli F, Guido M, Pavone V, Caruso A, et al. Preconceptional and gestational evaluation of insulin secretion in patients with polycystic ovary syndrome. Hum Reprod. 1996;11(11):2382-6.

4. Castelo-Branco C, Steinvarcel F, Osorio A, Ros C, Balasch J. Atherogenic metabolic profile in PCOS patients: role of obesity and hyperandrogenism. Gynecol Endocrinol. 2010;26(10):736-42.

5. Wild RA. Long-term health consequences of PCOS. Hum Reprod Update. 2002;8(3):231-41.

6. Boomsma CM, Eijkemans MJ, Hughes EG, Visser GH, Fauser BC, Macklon NS. A meta-analysis of pregnancy outcomes in women with polycystic ovary syndrome. Hum Reprod Update. 2006;12(6):673-83.

7. Kjerulff LE, Sanchez-Ramos L, Duffy D. Pregnancy outcomes in women with polycystic ovary syndrome: a metaanalysis. Am J Obstet Gynecol. 2011;204(6):558 e1-6.

8. Qin JZ, Pang LH, Li MJ, Fan XJ, Huang RD, Chen HY. Obstetric complications in women with polycystic ovary syndrome: a systematic review and meta-analysis. Reprod Biol Endocrinol. 2013;11:56.

9. Heijnen EM, Eijkemans MJ, Hughes EG, Laven JS, Macklon NS, Fauser BC. A meta-analysis of outcomes of conventional IVF in women with polycystic ovary syndrome. Hum Reprod Update. 2006;12(1):13-21.

10. Joham AE, Boyle JA, Ranasinha S, Zoungas S, Teede HJ. Contraception use and pregnancy outcomes in women with polycystic ovary syndrome: data from the Australian Longitudinal Study on Women's Health. Hum Reprod. 2014;29(4):802-8.

11. Roos N, Kieler H, Sahlin L, Ekman-Ordeberg G, Falconer H, Stephansson O. Risk of adverse pregnancy outcomes in women with polycystic ovary syndrome: population based cohort study. BMJ. 2011;343:d6309.

12. Naver KV, Grinsted J, Larsen SO, Hedley PL, Jorgensen FS, Christiansen M, et al. Increased risk of preterm delivery and pre-eclampsia in women with polycystic ovary syndrome and hyperandrogenaemia. BJOG. 2014;121(5):575-81.

13. Sterling L, Liu J, Okun N, Sakhuja A, Sierra S, Greenblatt E. Pregnancy outcomes in women with polycystic ovary syndrome undergoing in vitro fertilization. Fertil Steril. 2016;105(3):791-7 e2.

14. Thomann R, Rossinelli N, Keller U, Tirri BF, De Geyter C, Ruiz J, et al. Differences in low-grade chronic inflammation and insulin resistance in women with previous gestational diabetes mellitus and women with polycystic ovary syndrome. Gynecol Endocrinol. 2008;24(4):199-206.

15. Zavaroni I, Coruzzi P, Bonini L, Mossini GL, Musiari L, Gasparini P, et al. Association between salt sensitivity and insulin concentrations in patients with hypertension. Am J Hypertens. 1995;8(8):855-8. 
16. Sukalich S, Guzick D. Cardiovascular health in women with polycystic ovary syndrome. Semin Reprod Med. 2003;21(3):309-15.

17. Cho LW, Randeva HS, Atkin SL. Cardiometabolic aspects of polycystic ovarian syndrome. Vasc Health Risk Manag. 2007;3(1):55-63.

18. Poolsup N, Suksomboon N, Amin M. Effect of treatment of gestational diabetes mellitus: a systematic review and meta-analysis. PLoS One. 2014;9(3):e92485.

19. Toulis KA, Goulis DG, Kolibianakis EM, Venetis CA, Tarlatzis BC, Papadimas I. Risk of gestational diabetes mellitus in women with polycystic ovary syndrome: a systematic review and a meta-analysis. Fertil Steril. 2009;92(2):667-77.

20. Lao TT, Ho LF, Chan BC, Leung WC. Maternal age and prevalence of gestational diabetes mellitus. Diabetes Care. 2006;29(4):948-9.

21. Makgoba M, Savvidou MD, Steer PJ. An analysis of the interrelationship between maternal age, body mass index and racial origin in the development of gestational diabetes mellitus. BJOG. 2012;119(3):276-82.

22. Doyle P. The outcome of multiple pregnancy. Hum Reprod. 1996;11 Suppl 4:110-7; discussion 8-20.

23. Conde-Agudelo A, Belizan JM, Lindmark G. Maternal morbidity and mortality associated with multiple gestations. Obstet Gynecol. 2000;95(6 Pt 1):899-904.

24. Boomsma CM, Fauser BC, Macklon NS. Pregnancy complications in women with polycystic ovary syndrome. Semin Reprod Med. 2008;26(1):72-84.

25. Feghali M, Miodovnik M. Diabetes: hypertension during pregnancy and future diabetes mellitus. Nat Rev Endocrinol. 2013;9(8):446-7.

26. Fraser A, Nelson SM, Macdonald-Wallis C, Cherry L, Butler E, Sattar N, et al. Associations of pregnancy complications with calculated cardiovascular disease risk and cardiovascular risk factors in middle age: the Avon Longitudinal Study of Parents and Children. Circulation. 2012;125(11):1367-80.

TABLE 1.

Clinical characteristics of women with PCOS and controls during their first IVF treatment cycle.

\begin{tabular}{|c|c|c|c|}
\hline Maternal characteristics & $\operatorname{PCOS}(n=666)$ & Control $(n=7012)$ & $P$-valu \\
\hline Maternal age $(y)$ & $30.0(27.0-32.0)$ & $31.0(29.0-34.0)$ & $<0.00$ \\
\hline Maternal BMI (kg/m²) & $22.3(20.3-25.0)$ & $20.7(19.2-22.6)$ & $<0.00$ \\
\hline Type of infertility & & & $<0.00$ \\
\hline Primary & $445(66.8 \%)$ & $3587(51.2 \%)$ & \\
\hline Secondary & $221(33.2 \%)$ & $3425(48.8 \%)$ & \\
\hline Infertility duration (y) & $3.8 \pm 2.2$ & $3.7 \pm 2.6$ & $<0.00$ \\
\hline \multicolumn{4}{|l|}{ Infertility factors } \\
\hline Uterine and tubal factor & $50(7.5 \%)$ & $3375(48.1 \%)$ & $<0.00$ \\
\hline Ovulatory disorders & $489(73.4 \%)$ & $38(0.5 \%)$ & $<0.00$ \\
\hline Endometriosis & $15(2.3 \%)$ & $510(7.3 \%)$ & $<0.00$ \\
\hline Male factor & $8(1.2 \%)$ & $888(12.7 \%)$ & $<0.00$ \\
\hline Female and male factor & $94(14.1 \%)$ & $559(8.0 \%)$ & $<0.00$ \\
\hline Unexplained & $10(1.5 \%)$ & $1642(23.4 \%)$ & $<0.00$ \\
\hline Baseline FSH level (IU/L) & $5.1(4.3-6.0)$ & $5.6(4.7-6.8)$ & $<0.00$ \\
\hline Duration of gonadotropin stimulation (d) & $10.0(9.0-12.0)$ & $9.0(8.0-10.0)$ & $<0.00$ \\
\hline Total dose of gonadotropin (IU) & $1650.0(1350.0-2175.0)$ & $2400.0(1800.0-3000.0)$ & $<0.00$ \\
\hline Serum $\mathrm{E}_{2}$ level $(\mathrm{pg} / \mathrm{mL})$ on $\mathrm{hCG}$ day & $2602.0(1747.0-3740.8)$ & $2495.0(1734.3-3430.0)$ & 0.040 \\
\hline EMT $(\mathrm{mm})$ on hCG day & $11.0(10.0-13.0)$ & $11.0(10.0-13.0)$ & 0.737 \\
\hline
\end{tabular}




\begin{tabular}{llll}
\hline Maternal characteristics & PCOS $(\mathbf{n = 6 6 6 )}$ & Control (n=7012) & $P$-valu \\
\hline No. of oocyte retrieved & $15.0(12.0-19.0)$ & $13.0(9.0-17.0)$ & $<0.00$ \\
No. of fertilized occytes & $12.0(10.0-16.0)$ & $10.0(7.0-14.0)$ & $<0.00$ \\
No. of embryos transferred & $2.2 \pm 0.5$ & $2.4 \pm 0.7$ & $<0.00$ \\
Cycles with different technologies & Cycles with different technologies & & \\
IVF & $536(80.5 \%)$ & $5281(75.3 \%)$ & 0.003 \\
ICSI & $130(19.5 \%)$ & $1731(24.7 \%)$ & 0.430 \\
Embryo type & $609(91.4 \%)$ & $6472(92.3 \%)$ & \\
Cleavage embryo & $57(8.6 \%)$ & $540(7.7 \%)$ & \\
Blastocyst & & $6658(95.0 \%)$ & \\
Embryo quality & $650(97.6 \%)$ & $354(5.0 \%)$ & \\
Cycle with high-quality embryos & $16(2.4 \%)$ & & \\
Cycles without high-quality embryos & &
\end{tabular}

Note: $\mathrm{BMI}=$ body mass index; $\mathrm{E}_{2}=$ estradiol; $\mathrm{EMT}=$ endometrial thickness; $\mathrm{IVF}=\mathrm{in}$ vitro fertilization; $\mathrm{ICSI}=$ intracytoplasmic sperm injection; $\mathrm{hCG}=$ human chorionic gonadotropin .

Values are numbers (percentages) of cases, mean \pm standard deviation or median (interquartile range).

Continuous variables: Mann-Whitney $U$-test or independent $t$-test; categorical variables: Chi-square test or Fisher's exact test.

\section{TABLE 2.}

Pregnancy outcomes and complications of women with PCOS diagnosis and controls during their first IVF treatment cycle.

\begin{tabular}{|c|c|c|c|}
\hline Outcomes & $\operatorname{PCOS}(n=666)$ & Control $(n=7012)$ & $P$-value \\
\hline Implantation rate & $49.3 \%(732 / 1484)$ & $38.1 \%(6290 / 16521)$ & $<0.001$ \\
\hline Clinical pregnancy rate & $70.9 \%(472 / 666)$ & $59.8 \%(4190 / 7012)$ & $<0.001$ \\
\hline Miscarriage rate & $16.5 \%(78 / 472)$ & $11.2 \%(469 / 4190)$ & 0.001 \\
\hline Early miscarriage rate & $9.1 \%(43 / 472)$ & $7.8 \%(326 / 4190)$ & 0.310 \\
\hline Late miscarriage rate & $7.4 \%(35 / 472)$ & $3.4 \%(143 / 4190)$ & $<0.001$ \\
\hline Live birth rate & $58.3 \%(381 / 653)$ & $52.1 \%(3584 / 6874)$ & 0.002 \\
\hline Term delivery rate & $73.5 \%(280 / 381)$ & $78.1 \%(2800 / 3584)$ & 0.039 \\
\hline Preterm delivery rate & $26.5 \%(101 / 381)$ & $21.9 \%(784 / 3584)$ & $0.039 ? \gtreqless ?$ \\
\hline 34 and $<37$ weeks & $19.2 \%(73 / 381)$ & $17.9 \%(641 / 3584)$ & $0.538 ? j ?$ \\
\hline 32 and $<34$ weeks & $3.4 \%(13 / 381)$ & $2.3 \%(84 / 3584)$ & 0.199 \\
\hline$<32$ weeks weeks & $3.9 \%(15 / 381)$ & $1.6 \%(59 / 3584)$ & 0.002 \\
\hline Delivery type & & & 0.967 \\
\hline Cesarean & $26.8 \%(102 / 381)$ & $26.9 \%(963 / 3584)$ & \\
\hline Eutocia & $73.2 \%(279 / 381)$ & $73.1 \%(2621 / 3584)$ & \\
\hline No. of live babies delivered & & & 0.016 \\
\hline 1 & $58.0 \%(221 / 381)$ & $64.2 \%(2302 / 3584)$ & $? \gtreqless ?$ \\
\hline 2 & $42.0 \%(160 / 381)$ & $35.8 \%(1282 / 3584)$ & \\
\hline \multicolumn{4}{|l|}{ Pregnancy complications } \\
\hline Gestational diabetes mellitus & $9.7 \%(37 / 381)$ & $9.0 \%(324 / 3584)$ & 0.665 \\
\hline Pregnancy-induced hypertension & $3.9 \%(15 / 381)$ & $2.2 \%(78 / 3584)$ & 0.031 \\
\hline
\end{tabular}

Note: Categorical variables are presented as percentages (\%) and analyzed by Chi-square test or Fisher's exact test. 


\section{TABLE 3.}

Logistic regression analysis on the contribution of the potential predicting variables to live birth and clinical pregnancy outcomes.

\begin{tabular}{|c|c|c|c|c|c|c|c|c|c|c|c|}
\hline Variable & $\begin{array}{l}\text { Live } \\
\text { sbirth }\end{array}$ & $\begin{array}{l}\text { Live } \\
\text { birth }\end{array}$ & $\begin{array}{l}\text { Live } \\
\text { birth }\end{array}$ & $\begin{array}{l}\text { Live } \\
\text { birth }\end{array}$ & $\begin{array}{l}\text { Live } \\
\text { birth }\end{array}$ & $\begin{array}{l}\text { Live } \\
\text { birth }\end{array}$ & $\begin{array}{l}\text { Clinical } \\
\text { preg- } \\
\text { nancy }\end{array}$ & $\begin{array}{l}\text { Clinical } \\
\text { preg- } \\
\text { nancy }\end{array}$ & $\begin{array}{l}\text { Clinical } \\
\text { preg- } \\
\text { nancy }\end{array}$ & $\begin{array}{l}\text { Clinical } \\
\text { preg- } \\
\text { nancy }\end{array}$ & $\begin{array}{l}\text { Clinical } \\
\text { preg- } \\
\text { nancy }\end{array}$ \\
\hline & $\begin{array}{l}\text { OR } \\
(95 \% \\
\text { CI })\end{array}$ & $\begin{array}{l}P \text { - } \\
\text { value }\end{array}$ & $\begin{array}{l}\text { Adjust } \\
\text { OR } \\
(95 \% \\
\text { CI })^{\mathrm{a}}\end{array}$ & $\begin{array}{l}\mathrm{d} P- \\
\text { value }^{\mathrm{a}}\end{array}$ & $\begin{array}{l}\text { Adjust } \\
\text { OR } \\
(95 \% \\
\text { CI })^{b}\end{array}$ & $\begin{array}{l}\mathrm{d} P- \\
\text { value }^{\mathbf{b}}\end{array}$ & $\begin{array}{l}\text { OR } \\
(95 \% \\
\text { CI })\end{array}$ & $\begin{array}{l}P \text { - } \\
\text { value }\end{array}$ & $\begin{array}{l}\text { Adjustec } \\
\text { OR } \\
(95 \% \\
\text { CI })^{\mathrm{a}}\end{array}$ & $\begin{array}{l}\mathrm{d} P- \\
\text { value }^{\mathrm{a}}\end{array}$ & $\begin{array}{l}\text { Adjusted } \\
\text { OR } \\
(95 \% \\
\text { CI })^{b}\end{array}$ \\
\hline $\begin{array}{l}\text { PCOS } \\
\text { diag- } \\
\text { nosis }\end{array}$ & $\begin{array}{l}1.287 \\
(1.093- \\
1.514)\end{array}$ & 0.002 & $\begin{array}{l}1.213 \\
(1.027- \\
1.433)\end{array}$ & 0.023 & $\begin{array}{l}1.012 \\
(0.852- \\
1.204)\end{array}$ & 0.888 & $\begin{array}{l}1.639 \\
(1.377- \\
1.950)\end{array}$ & $\begin{array}{l}< \\
0.001\end{array}$ & $\begin{array}{l}1.532 \\
(1.284- \\
1.830)\end{array}$ & $\begin{array}{l}< \\
0.001\end{array}$ & $\begin{array}{l}1.248 \\
(1.038- \\
1.501)\end{array}$ \\
\hline Materna & al0.959 & $<$ & 0.960 & $<$ & 0.983 & 0.021 & 0.971 & $<$ & 0.972 & $<$ & 0.993 \\
\hline $\begin{array}{l}\text { age } \\
(\mathrm{y})\end{array}$ & $\begin{array}{l}(0.947- \\
0.971)\end{array}$ & 0.001 & $\begin{array}{l}(0.948- \\
0.972)\end{array}$ & 0.001 & $\begin{array}{l}(0.968- \\
0.997)\end{array}$ & & $\begin{array}{l}(0.959- \\
0.984)\end{array}$ & 0.001 & $\begin{array}{l}(0.960- \\
0.985)\end{array}$ & 0.001 & $\begin{array}{l}(0.978- \\
1.008)\end{array}$ \\
\hline $\begin{array}{l}\text { Materna } \\
\text { BMI } \\
\left(\mathrm{kg} / \mathrm{m}^{2}\right)\end{array}$ & $\begin{array}{c}10.999 \\
(0.983- \\
1.016)\end{array}$ & 0.946 & $\begin{array}{l}1.004 \\
(0.987- \\
1.021)\end{array}$ & 0.677 & $\begin{array}{l}0.996 \\
(0.979- \\
1.014)\end{array}$ & 0.667 & $\begin{array}{l}1.021 \\
(1.004- \\
1.038)\end{array}$ & 0.014 & $\begin{array}{l}1.020 \\
(1.002- \\
1.037)\end{array}$ & 0.026 & $\begin{array}{l}1.008 \\
(0.990- \\
1.027)\end{array}$ \\
\hline $\begin{array}{l}\text { Infertilit } \\
\text { dura- } \\
\text { tion } \\
\text { (y) }\end{array}$ & $\begin{array}{l}(0.957- \\
0.991)\end{array}$ & 0.003 & & & $\begin{array}{l}0.989 \\
(0.971- \\
1.008)\end{array}$ & 0.271 & $\begin{array}{l}0.986 \\
(0.969- \\
1.004)\end{array}$ & 0.126 & & & $\begin{array}{l}0.996 \\
(0.977- \\
1.016)\end{array}$ \\
\hline $\begin{array}{l}\text { Total } \\
\text { dose } \\
\text { of go- } \\
\text { nadotrop } \\
(\mathrm{IU})^{1}\end{array}$ & $\begin{array}{l}0.718 \\
(0.679- \\
0.759) \\
\text { pin }\end{array}$ & $\begin{array}{l}< \\
0.001\end{array}$ & & & $\begin{array}{l}0.798 \\
(0.750- \\
0.850)\end{array}$ & $\begin{array}{l}< \\
0.001\end{array}$ & $\begin{array}{l}0.682 \\
(0.645- \\
0.722)\end{array}$ & $\begin{array}{l}< \\
0.001\end{array}$ & & & $\begin{array}{l}0.753 \\
(0.707- \\
0.802)\end{array}$ \\
\hline $\begin{array}{l}\text { Serum } \\
\mathrm{E}_{2} \\
\text { level } \\
(\mathrm{pg} / \mathrm{mL}) \\
\text { on } \\
\mathrm{hCG} \\
\text { day }^{2}\end{array}$ & $\begin{array}{l}1.057 \\
(1.028- \\
1.087)\end{array}$ & $\begin{array}{l}< \\
0.001\end{array}$ & & & $\begin{array}{l}0.968 \\
(0.936- \\
1.001)\end{array}$ & 0.058 & $\begin{array}{l}1.045 \\
(1.016- \\
1.075)\end{array}$ & 0.002 & & & $\begin{array}{l}0.939 \\
(0.907- \\
0.972)\end{array}$ \\
\hline $\begin{array}{l}\text { EMT } \\
(\mathrm{mm}) \\
\text { on } \\
\text { hCG } \\
\text { day }\end{array}$ & $\begin{array}{l}1.087 \\
(1.066- \\
1.109)\end{array}$ & $\begin{array}{l}< \\
0.001\end{array}$ & & & $\begin{array}{l}1.091 \\
(1.069- \\
1.114)\end{array}$ & $\begin{array}{l}< \\
0.001\end{array}$ & $\begin{array}{l}1.087 \\
(1.065- \\
1.109)\end{array}$ & $\begin{array}{l}< \\
0.001\end{array}$ & & & $\begin{array}{l}1.092 \\
(1.070- \\
1.115)\end{array}$ \\
\hline $\begin{array}{l}\text { No. of } \\
\text { fertil- } \\
\text { ized } \\
\text { oc- } \\
\text { cytes }\end{array}$ & $\begin{array}{l}1.050 \\
(1.041- \\
1.060)\end{array}$ & $\begin{array}{l}< \\
0.001\end{array}$ & & & $\begin{array}{l}1.030 \\
(1.018- \\
1.041)\end{array}$ & $\begin{array}{l}< \\
0.001\end{array}$ & $\begin{array}{l}1.057 \\
(1.047- \\
1.067)\end{array}$ & $\begin{array}{l}< \\
0.001\end{array}$ & & & $\begin{array}{l}1.037 \\
(1.025- \\
1.049)\end{array}$ \\
\hline $\begin{array}{l}\text { No. of } \\
\text { em- } \\
\text { bryos } \\
\text { trans- } \\
\text { ferred }\end{array}$ & $\begin{array}{l}0.880 \\
(0.821- \\
0.943)\end{array}$ & $\begin{array}{l}< \\
0.001\end{array}$ & & & $\begin{array}{l}1.009 \\
(0.930- \\
1.095)\end{array}$ & 0.830 & $\begin{array}{l}0.952 \\
(0.888- \\
1.021)\end{array}$ & 0.169 & & & $\begin{array}{l}1.115 \\
(1.026- \\
1.211)\end{array}$ \\
\hline
\end{tabular}




\begin{tabular}{|c|c|c|c|c|c|c|c|c|c|c|c|}
\hline Variables & $\begin{array}{l}\text { Live } \\
\text { sbirth }\end{array}$ & $\begin{array}{l}\text { Live } \\
\text { birth }\end{array}$ & $\begin{array}{l}\text { Live } \\
\text { birth }\end{array}$ & $\begin{array}{l}\text { Live } \\
\text { birth }\end{array}$ & $\begin{array}{l}\text { Live } \\
\text { birth }\end{array}$ & $\begin{array}{l}\text { Live } \\
\text { birth }\end{array}$ & $\begin{array}{l}\text { Clinical } \\
\text { preg- } \\
\text { nancy }\end{array}$ & $\begin{array}{l}\text { Clinical } \\
\text { preg- } \\
\text { nancy }\end{array}$ & $\begin{array}{l}\text { Clinical } \\
\text { preg- } \\
\text { nancy }\end{array}$ & $\begin{array}{l}\text { Clinical } \\
\text { preg- } \\
\text { nancy }\end{array}$ & $\begin{array}{l}\text { Clinical } \\
\text { preg- } \\
\text { nancy }\end{array}$ \\
\hline \multicolumn{12}{|l|}{$\begin{array}{l}\text { Embryo } \\
\text { type }\end{array}$} \\
\hline $\begin{array}{l}\text { Cleavage } \\
\text { embryo }\end{array}$ & Ref & Ref & & & Ref & Ref & Ref & Ref & & & Ref \\
\hline Blastocyst & $\begin{array}{l}\mathrm{t} 2.005 \\
(1.667- \\
2.410)\end{array}$ & $\begin{array}{l}< \\
0.001\end{array}$ & & & $\begin{array}{l}1.951 \\
(1.603- \\
2.376)\end{array}$ & $\begin{array}{l}< \\
0.001\end{array}$ & $\begin{array}{l}2.126 \\
(1.753- \\
2.578)\end{array}$ & $\begin{array}{l}< \\
0.001\end{array}$ & & & $\begin{array}{l}2.210 \\
(1.797- \\
2.719)\end{array}$ \\
\hline \multicolumn{12}{|l|}{$\begin{array}{l}\text { Embryo } \\
\text { qual- } \\
\text { ity }\end{array}$} \\
\hline $\begin{array}{l}\text { Cycle } \\
\text { with } \\
\text { high- } \\
\text { quality } \\
\text { embryos }\end{array}$ & Ref & Ref & & & Ref & Ref & Ref & Ref & & & Ref \\
\hline $\begin{array}{l}\text { Cycles } \\
\text { with- } \\
\text { out } \\
\text { high- } \\
\text { quality } \\
\text { embryos }\end{array}$ & $\begin{array}{l}0.209 \\
(0.161- \\
0.272)\end{array}$ & $\begin{array}{l}< \\
0.001\end{array}$ & & & $\begin{array}{l}0.257 \\
(0.197- \\
0.336)\end{array}$ & $\begin{array}{l}< \\
0.001\end{array}$ & $\begin{array}{l}0.210 \\
(0.166- \\
0.267)\end{array}$ & $\begin{array}{l}< \\
0.001\end{array}$ & & & $\begin{array}{l}0.270 \\
(0.211- \\
0.345)\end{array}$ \\
\hline
\end{tabular}

Note: All the variables inputted in the model were shown in Table 3. BMI=body mass index; $\mathrm{CI}=$ confidence interval; $\mathrm{OR}=$ odds ratio; $\mathrm{E}_{2}=$ estradiol; $\mathrm{hCG}=$ human chorionic gonadotropin; $\mathrm{EMT}=$ endometrial thickness; Ref $=$ reference; ${ }^{1}$ per $1000 \mathrm{IU}$ increased; ${ }^{2}$ per $1000 \mathrm{pg} / \mathrm{mL}$ increased.

${ }^{a}$ Adjusted for maternal age and BMI.

${ }^{\mathrm{b}}$ Adjusted for maternal age, BMI, infertility duration, total dose of gonadotropin, serum $\mathrm{E}_{2}$ level and endometrial thickness on hCG day, number of fertilized occytes, number of embryos transferred, embryo type and embryo quality.

TABLE 4.

Univariable and multivariable regression analysis of risk of miscarriage, preterm delivery and pregnancyinduced hypertension.

\begin{tabular}{|c|c|c|c|c|c|c|c|}
\hline Outcomes & Variables & $\begin{array}{l}\text { OR }(95 \% \\
\text { CI })\end{array}$ & $P$-value & $\begin{array}{l}\text { Adjusted } \\
\text { OR }(95 \% \\
\text { CI })^{\mathrm{a}}\end{array}$ & $P$-value ${ }^{\text {a }}$ & $\begin{array}{l}\text { Adjusted } \\
\text { OR } \\
(95 \% \text { CI })^{b}\end{array}$ & $P$-value ${ }^{\mathbf{b}}$ \\
\hline \multirow[t]{3}{*}{ Miscarriage } & $\begin{array}{l}\text { PCOS } \\
\text { diagnosis }\end{array}$ & $\begin{array}{l}1.571(1.210- \\
2.039)\end{array}$ & 0.001 & $\begin{array}{l}1.585(1.210- \\
2.078)\end{array}$ & 0.001 & $\begin{array}{l}1.629(1.240- \\
2.141)\end{array}$ & $<0.001$ \\
\hline & $\begin{array}{l}\text { Maternal } \\
\text { age }(y)\end{array}$ & $\begin{array}{l}1.070(1.043- \\
1.098)\end{array}$ & $<0.001$ & $\begin{array}{l}1.069(1.042- \\
1.098)\end{array}$ & $<0.001$ & $\begin{array}{l}1.037(1.007- \\
1.067)\end{array}$ & 0.015 \\
\hline & $\begin{array}{l}\text { Maternal } \\
\text { BMI } \\
\left(\mathrm{kg} / \mathrm{m}^{2}\right)\end{array}$ & $\begin{array}{l}1.072(1.040- \\
1.106)\end{array}$ & $<0.001$ & $\begin{array}{l}1.051(1.018- \\
1.086)\end{array}$ & 0.002 & $\begin{array}{l}1.046(1.012- \\
1.080)\end{array}$ & 0.008 \\
\hline
\end{tabular}




\begin{tabular}{|c|c|c|c|c|c|c|c|}
\hline Outcomes & Variables & $\begin{array}{l}\text { OR }(95 \% \\
\text { CI })\end{array}$ & $P$-value & $\begin{array}{l}\text { Adjusted } \\
\text { OR }(95 \% \\
\text { CI })^{a}\end{array}$ & $P$-value ${ }^{\mathbf{a}}$ & $\begin{array}{l}\text { Adjusted } \\
\text { OR } \\
(95 \% \mathrm{CI})^{\mathrm{b}}\end{array}$ & $P$-value ${ }^{\mathrm{b}}$ \\
\hline & $\begin{array}{l}\text { Infertility } \\
\text { duration } \\
(y)\end{array}$ & $\begin{array}{l}1.054 \\
(1.019- \\
1.089)\end{array}$ & 0.002 & & & $\begin{array}{l}1.021 \\
(0.986- \\
1.057)\end{array}$ & 0.237 \\
\hline & $\begin{array}{l}\text { Serum } E_{2} \\
\text { level } \\
(\mathrm{pg} / \mathrm{mL}) \\
\text { on } \mathrm{hCG} \\
\text { day }^{2}\end{array}$ & $\begin{array}{l}0.925(0.871- \\
0.982)\end{array}$ & 0.010 & & & $\begin{array}{l}0.945(0.890- \\
1.004)\end{array}$ & 0.069 \\
\hline & $\begin{array}{l}\text { EMT } \\
(\mathrm{mm}) \text { on } \\
\text { hCG day }\end{array}$ & $\begin{array}{l}0.953(0.917- \\
0.991)\end{array}$ & 0.015 & & & $\begin{array}{l}0.949(0.912- \\
0.987)\end{array}$ & 0.009 \\
\hline & $\begin{array}{l}\text { No. of } \\
\text { embryos } \\
\text { transferred } \\
\text { Embryo } \\
\text { type }\end{array}$ & $\begin{array}{l}1.473(1.296- \\
1.674)\end{array}$ & $<0.001$ & & & $\begin{array}{l}1.348 \\
1.565)\end{array}$ & $<0.001$ \\
\hline & $\begin{array}{l}\text { Cleavage } \\
\text { embryo }\end{array}$ & Ref & Ref & & & Ref & Ref \\
\hline & Blastocyst & $\begin{array}{l}0.566(0.393- \\
0.817)\end{array}$ & 0.002 & & & $\begin{array}{l}0.693(0.472- \\
1.017)\end{array}$ & 0.061 \\
\hline & $\begin{array}{l}\text { Embryo } \\
\text { quality }\end{array}$ & & & & & & \\
\hline & $\begin{array}{l}\text { Cycle with } \\
\text { high-quality } \\
\text { embryos }\end{array}$ & Ref & Ref & & & Ref & Ref \\
\hline & $\begin{array}{l}\text { Cycles } \\
\text { without } \\
\text { high-quality } \\
\text { embryos }\end{array}$ & $\begin{array}{l}1.887(1.133- \\
3.143)\end{array}$ & 0.015 & & & $\begin{array}{l}1.846 \\
3.104)\end{array}$ & 0.021 \\
\hline \multirow{6}{*}{$\begin{array}{l}\text { Preterm } \\
\text { delivery (< } \\
37 \text { weeks) }\end{array}$} & $\begin{array}{l}\text { PCOS } \\
\text { diagnosis }\end{array}$ & $\begin{array}{l}1.288(1.012- \\
1.639)\end{array}$ & 0.040 & $\begin{array}{l}1.236(0.966- \\
1.582)\end{array}$ & 0.092 & $\begin{array}{l}1.206(0.937- \\
1.552)\end{array}$ & 0.145 \\
\hline & $\begin{array}{l}\text { Maternal } \\
\text { age }(y)\end{array}$ & $\begin{array}{l}0.985(0.964- \\
1.006)\end{array}$ & 0.158 & $\begin{array}{l}0.985(0.964- \\
1.007)\end{array}$ & 0.172 & $\begin{array}{l}0.970(0.947- \\
0.993)\end{array}$ & 0.011 \\
\hline & $\begin{array}{l}\text { Maternal } \\
\text { BMI } \\
\left(\mathrm{kg} / \mathbf{m}^{2}\right)\end{array}$ & $\begin{array}{l}1.016(0.989- \\
1.044)\end{array}$ & 0.243 & $\begin{array}{l}1.015(0.987- \\
1.044)\end{array}$ & 0.285 & $\begin{array}{l}1.016(0.988- \\
1.045)\end{array}$ & 0.272 \\
\hline & $\begin{array}{l}\text { Total dose } \\
\text { of go- } \\
\text { nadotropin } \\
(\mathrm{IU})^{1}\end{array}$ & $\begin{array}{l}0.903(0.821- \\
0.994)\end{array}$ & 0.037 & & & $\begin{array}{l}0.931(0.839- \\
1.033)\end{array}$ & 0.179 \\
\hline & $\begin{array}{l}\text { No. of } \\
\text { fertilized } \\
\text { occytes }\end{array}$ & $\begin{array}{l}1.017(1.002- \\
1.032)\end{array}$ & 0.023 & & & $\begin{array}{l}1.009(0.993- \\
1.025)\end{array}$ & 0.263 \\
\hline & $\begin{array}{l}\text { No. of } \\
\text { embryos } \\
\text { transferred }\end{array}$ & $\begin{array}{l}1.209 \\
1.359)\end{array}$ & 0.002 & & & $\begin{array}{l}1.431 \\
1.632)\end{array}$ & $<0.001$ \\
\hline
\end{tabular}




\begin{tabular}{|c|c|c|c|c|c|c|c|}
\hline Outcomes & Variables & $\begin{array}{l}\text { OR }(95 \% \\
\text { CI })\end{array}$ & $P$-value & $\begin{array}{l}\text { Adjusted } \\
\text { OR }(95 \% \\
\text { CI })^{\mathrm{a}}\end{array}$ & $P$-value ${ }^{\text {a }}$ & $\begin{array}{l}\text { Adjusted } \\
\text { OR } \\
(95 \% \text { CI })^{b}\end{array}$ & $P$-value ${ }^{\mathrm{b}}$ \\
\hline & $\begin{array}{l}\text { Embryo } \\
\text { type }\end{array}$ & & & & & & \\
\hline & $\begin{array}{l}\text { Cleavage } \\
\text { embryo }\end{array}$ & Ref & Ref & & & Ref & Ref \\
\hline & Blastocyst & $\begin{array}{l}1.622(1.285- \\
2.047)\end{array}$ & $<0.001$ & & & $\begin{array}{l}1.976(1.545- \\
2.528)\end{array}$ & $<0.001$ \\
\hline \multirow{3}{*}{$\begin{array}{l}\text { Preterm } \\
\text { delivery (< } \\
32 \text { weeks) }\end{array}$} & $\begin{array}{l}\text { PCOS } \\
\text { diagnosis }\end{array}$ & $\begin{array}{l}2.448(1.375- \\
4.358)\end{array}$ & 0.002 & $\begin{array}{l}2.135(1.170- \\
3.895)\end{array}$ & 0.013 & $\begin{array}{l}2.135(1.170- \\
3.895)\end{array}$ & 0.013 \\
\hline & $\begin{array}{l}\text { Maternal } \\
\text { age }(y)\end{array}$ & $\begin{array}{l}0.934(1.003- \\
1.071)\end{array}$ & 0.934 & $\begin{array}{l}1.002(0.937- \\
1.072)\end{array}$ & 0.948 & $\begin{array}{l}1.002(0.937- \\
1.072)\end{array}$ & 0.948 \\
\hline & $\begin{array}{l}\text { Maternal } \\
\text { BMI } \\
\left(\mathrm{kg} / \mathrm{m}^{2}\right)\end{array}$ & $\begin{array}{l}1.114(1.032- \\
1.204)\end{array}$ & 0.006 & $\begin{array}{l}1.094(1.010- \\
1.184)\end{array}$ & 0.028 & $\begin{array}{l}1.094(1.010- \\
1.184)\end{array}$ & 0.028 \\
\hline \multirow{5}{*}{$\begin{array}{l}\text { Pregnancy- } \\
\text { induced } \\
\text { hyperten- } \\
\text { sion }\end{array}$} & $\begin{array}{l}\text { PCOS } \\
\text { diagnosis }\end{array}$ & $\begin{array}{l}1.842(1.049- \\
3.234)\end{array}$ & 0.034 & $\begin{array}{l}1.784(0.996- \\
3.197)\end{array}$ & 0.052 & $\begin{array}{l}1.764(0.981- \\
3.171)\end{array}$ & 0.058 \\
\hline & $\begin{array}{l}\text { Maternal } \\
\text { age }(y)\end{array}$ & $\begin{array}{l}1.042(0.982- \\
1.106)\end{array}$ & 0.171 & $\begin{array}{l}1.043(0.981- \\
1.108)\end{array}$ & 0.177 & $\begin{array}{l}1.017(0.955- \\
1.084)\end{array}$ & 0.595 \\
\hline & $\begin{array}{l}\text { Maternal } \\
\text { BMI } \\
\left(\mathrm{kg} / \mathrm{m}^{2}\right)\end{array}$ & $\begin{array}{l}1.077(1.003- \\
1.156)\end{array}$ & 0.040 & $\begin{array}{l}1.057(0.982- \\
1.137)\end{array}$ & 0.143 & $\begin{array}{l}1.032(0.958- \\
1.111)\end{array}$ & 0.412 \\
\hline & $\begin{array}{l}\text { Infertility } \\
\text { duration } \\
(\mathrm{y})\end{array}$ & $\begin{array}{l}1.098(1.023- \\
1.178)\end{array}$ & 0.010 & & & $\begin{array}{l}1.081(1.003- \\
1.165)\end{array}$ & 0.042 \\
\hline & $\begin{array}{l}\text { Serum } \mathrm{E}_{2} \\
\text { level } \\
(\mathrm{pg} / \mathrm{mL}) \\
\text { on } \mathrm{hCG} \\
\text { day }^{2}\end{array}$ & $\begin{array}{l}0.803(0.683- \\
0.945)\end{array}$ & 0.008 & & & $\begin{array}{l}0.824(0.700- \\
0.969)\end{array}$ & 0.020 \\
\hline
\end{tabular}

Note: All the variables inputted in the model were shown in Table 4 . BMI=body mass index; $\mathrm{CI}=$ confidence interval; $\mathrm{OR}=$ odds ratio; $\mathrm{E}_{2}=$ estradiol; $\mathrm{hCG}=$ human chorionic gonadotropin; $\mathrm{EMT}=$ endometrial thickness; Ref $=$ reference; ${ }^{1}$ per $1000 \mathrm{IU}$ increased; ${ }^{2}$ per $1000 \mathrm{pg} / \mathrm{mL}$ increased.

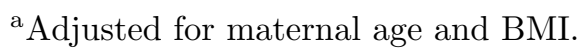

${ }^{\mathrm{b}}$ Adjusted for maternal age, BMI, and other variables based on the univariate logistic regression model.

Figure legend

Supplemental Figure 1. Flow chart showing the identification of the study population. 